\title{
Pengaruh Tingkat Pengetahuan Terhadap Penanggulangan Tuberculosis
}

\author{
Aliyuna Septaningrum \\ IIK Surya Mitra Husada ( Ilmu Kesehatan Masyarakat ) \\ ayun3140@gmail.com
}

\begin{abstract}
Abstrak
Masalah kesehatan yang masih terjadi di masyarakat salah satunya adalah penyakit TB. Penyakit ini tergolong sebagai salah satu jenis penyakit menular. Tuberculosis adalah suatu penyakit menular yang sebagian besar disebabkan oleh kuman mycobacterium tuberculosis. Dengan masih tingginya penderita TB di Indonesia disebabkan oleh rendahnya pengetahuan. Beberapa faktor yang mempengaruhi pengetahuan adalah pendidikan, umur, pekerjaan, social budaya, dan lingkungan. Dengan meningkatkan pengetahuan masyarakat salah satunya dengan pemberian informasi tentang TB akan menanggulangi penyakit TB.
\end{abstract}

\section{Latar Belakang}

Tuberculosis sampai saat ini masih menjadi salah satu masalah kesehatan masyarakat di Indonesia, walaupun upaya penanganan TB telah dilaksanakan di Indonesia. Penyakit TB disebabkan oleh Kuman Mycobacterium Tuberculosis yang sering sekali menginfeksi organ tubuh bagian paru daripada organ tubuh lainnya yang ditularkan melalui droplet (percikan dahak penderita). Penemuan kasus TB ini disebabkan juga atas masih kurangnya pengetahuan masyarakat tentang penyebab TB dan penanganannya.

Menurut laporan WHO tahun 2015 diperkirakan ada penderita 1 juta kasus TB baru setiap tahunnya (399 per 100.000 penduduk). Di Indonesia dengan jumlah penduduk yang besar, dapat memberikan kontribusi yang besar pula terhadap cakupan program TB. Di Kabupaten Kediri Provinsi Jawa Timur pada tahun 2018 target capaian kasus adalah 1689 kasus $(53,50 \%)$. Berdasarkan jenis kelamin penderita TB sebanyak, laki-laki 878 orang $(52,55 \%)$ dan perempuan 811 orang (47,45\%). (Profil Kesehatan Kabupaten Kediri Tahun 2018)

Penanganan TB dilakukan melalui strategi DOTS (Directly Observed Treatment Shortcourse), yaitu strategi pengobatan dengan menggunakan pemeriksaan mikroskopis sebagai sarana diagnosis, pengobatan jangka pendek dengan pengawasan langsung oleh 
seorang PMO (Pengawas Menelan Obat), dengan adanya jaminan ketersediaan obat serta dilakukan pencatatan standart. Komitmen dari penderita dan pengawas menjadi unsur penting dari strategi ini untuk pencapaian target.

\section{Kasus/Masalah}

Bagaimana pengaruh tingkat pengetahuan masyarakat terhadap penanggulangan TB ?

\section{Tinjauan Pustaka}

A. Pengetahuan

1.Pengertian

Menurut Notoatmodjo pengetahuan adalah hasil dari tahu dan ini terjadi setelah orang mengadakan pengindraan terhadap suatu objek tertentu.

2. Tingkat Pengetahuan

Tahu, Memahami, Aplikasi, Analisis, Sintesis, dan Evaluasi.

3. Cara memperoleh pengetahuan
a. Cara coba salah
b. Cara kekuasaan atau otoritas
c. Berdasarkan pengalaman pribadi
d. Metodologi penelitian

4.Faktor-faktor yang mempengaruhi pengetahuan

a. Faktor Internal

1. Pendidikan

2. Pekerjaan

3. Umur

b. Faktor Eksternal

1. Faktor Lingkungan

2. Faktor Sosial Budaya

3.Kriteria tingkat pengetahuan

1. Pengetahuan Baik : $76-100 \%$

2. Pengetahuan Cukup : :56-75\%

3. Pengetahuan Kurang : :40-55\% 
4. Pengetahuan Tidak Baik $\quad:<40 \%$

(A.Wawan dan Dewi,2010, hal :12-18)

B. Tuberculosis

1. Pengertian

Tuberculosis adalah suatu penyakit menular yang sebagian besar disebabkan oleh kuman mycobacterium tuberculosis. Kuman tersebut biasanya masuk ke dalam tubuh manusia melalui udara yang dihirup ke dalam paru, kemudian kuman tersebut dapat menyebar dari paru ke bagian tubuh lain melalui system peredaran darah, system daluran limfa, melalui saluran pernafasan (broncus) atau penyebaran langsung ke bagian-bagian tubuh lainnya. (Kesehatan Masyarakat, hal 322-323)

2. Faktor Predisposisi

a. Kontak dengan penderita tuberculosis

b. Nutrisi kurang

c. Faktor sosioekonomi

3. Tanda dan Gejala

Gejala Utama :

Batuk berdahak selama 2-3 minggu atau lebih

Gejala tambahan :

a. Dahak bercampur darah atau batuk darah

b. Sesak nafas

c. Badan lemas

d. Nafsu makan menurun

e. Berat badan menurun

f. Malaise

g. Berkeringat malam hari tanpa kegiatan fisik

h. Demam meriang lebih dari satu bulan

4. Diagnosis

Pemeriksaan dahak dengan pewarnaan BTA dilakukan dengan metode SPS (sewaktu-pagi-sewaktu) sebanyak tiga kali pengambilan, yaitu saat pertama kali 
berkunjung, kemudian setelah bangun tidur pagi di hari kedua (pot dahak dibawa pulang), dan saat menyerahkan pot dahak di hari kedua.

(Buku Saku, hal 168)

5. Penanggulangan

Tujuan penanggulangan :

Memutuskan rantai penularan penyakit TB, Tercapainya kesembuhan minimal 85\% penderita baru BTA positif yang ditemukan, tercapainya cakupan penemuan semua penderita secara bertahap, Tercegahnya resistensi obat TB di masyarakat.

Kegiatan yang dilakukan dalam menanggulangi :

Pengobatan yang cukup dan tepat dan Pengawasan menelan obat setiap hari terutama pada fase awal 2. (Kesehatan Masyarakat, hal : 326-327)

\section{Pembahasan}

Hasil dari teori diatas menunjukkan bahwa semakin tinggi atau semakin baik pengetahuan seseorang terhadap sesuatu objek maka akan semakin baik pula sikap seseorang tersebut terhadap objek itu. Pengetahuan seseorang dipengaruhi oleh banyak hal antara lain pendidikan, pengalaman, lingkungan. Dengan pendidikan seseorang akan lebih cenderung untuk mendapatkan informasi sebanyak mungkin. Informasi yang banyak tersebut akan menambah pengetahuan seseorang mengenai pelbagai hal.

Dengan mudahnya seseorang mendapatkan informasi terutama mengenai kesehatan, itu akan berdampak pada meningkatnya derajat kesehatan seseorang. Dalam hal ini dengan pendidikan yang baik seseorang akan mencari tahu mengenai penyakit TB itu apa, bagaimana bisa tertular TB, apa saja gejala yang timbul akibat penyakit TB, bagaimana cara pengecekan TB, dan penanganan atau pengobatan rutin yang harus dilakukan. Pengetahuan yang memadai akan meminimalisir angka terjadinya TB di masyarakat.

\section{Kesimpulan}

Dari pembahasan diatas dapat ditarik kesimpulan sebagai berikut :

1. Pengetahuan didapat melalui banyaknya informasi yang diperoleh

2. Dengan banyaknya informasi tentang TB yang diperoleh akan mengurangi penyebaran TB

3. Adanya pengaruh tingkat pengetahuan dalam menanggulangi penyakit TB 


\section{Daftar Pustaka}

A. Wawan dan Dewi M.2010.Teori dan Pengukuran Pengetahuan, Sikap, dan Perilaku Manusia.Yogyakarta:Nuha Medika.

Astuti, S. (2013). Hubungan tingkat pengetahuan dan sikap masyarakat terhadap upaya pencegahan penyakit Tuberkulosis di rw 04 Kelurahan Lagoa Jakarta Utara Tahun 2013.

Djannah, S. N., Suryani, D., \& Purwati, D. A. (2009). Hubungan tingkat pengetahuan dan sikap dengan perilaku pencegahan penularan TBC pada mahasiswa di asrama manokwari Sleman Yogyakarta. Universitas Ahmad Dahlan.

Http://www.dinkes.kedirikab.go.id/?hal=dprofilkesehatan\&id=53. Diakses pada tanggal 05 Januari 2019.

Kemenkes RI.2013.Buku Saku Pelayanan Kesehatan Ibu di Fasilitas Kesehatan Dasar dan Rujukan.Jakarta: Kemenkes RI.

Muniroh, N., \& Aisah, S. (2013). Faktor-faktor yang berhubungan dengan kesembuhan penyakit tuberculosis (TBC) paru di wilayah kerja puskesmas Mangkang Semarang Barat. Jurnal keperawatan komunitas, 1(1).

Notoatmojo, Soekidjo.2011.Kesehatan Masyarakat Ilmu dan Seni.Jakarta: Rineka Cipta. 